\title{
Longitudinal habitat disruption in Neotropical streams: fish assemblages under the influence of culverts
}

\author{
José Roberto Mariano ${ }^{1,2}$, Maristela Cavicchioli Makrakis², Elaine Antoniassi Luiz \\ Kashiwaqui $^{3}$, Elaine Fernandes Celestino ${ }^{1,2}$ and Sergio Makrakis ${ }^{2}$
}

This study assessed differences in fish assemblages existing upstream and downstream two types of culverts, one on each of two different Neotropical streams. We analyzed the composition and structure of the ichthyofauna and tested for spatial patterns. Fish sampling was carried out monthly between November 2009 and October 2010 using different fishing gears. We collected 2,220 fish of 33 species; 901 in stretches of the Lopeí stream - circular culvert and 1,310 in stretches of the Pindorama stream - box culvert. Fish abundance was similar in upstream and downstream stretches of the circular culvert, whereas it was slightly higher in the upstream than downstream stretch for the box culvert. Characiformes predominated in the upstream stretch of both culverts. On the other hand, Siluriformes was abundant in the downstream stretch of the circular culvert, with similar abundance in the stretches of the box culvert. Species richness and diversity (Shannon-Weiner Index) were higher in the downstream stretch of the circular culvert, but they were similar in both stretches of the box culvert. The most abundant species were Astyanax altiparanae, A. paranae, A. fasciatus, Ancistrus sp., and Hypostomus $\mathrm{sp}$. The last two species were more abundant in the downstream stretch of the circular culvert, and similar in stretches of the box culvert. Our study indicated variations in the species abundance, richness, and diversity between upstream and downstream stretches in particular of the circular culvert in the Lopeí stream, suggesting that fish movements are restrained more intensively in this culvert, especially for Siluriformes. The drop in the circular culvert outlet probably created passage barriers especially for those fish that has no ability to jump, where downstream erosion could lead to culvert perching. Studies on appropriate road crossing design or installation are fundamental whereas improvements in these structures can restore the connectivity of fish populations and communities in streams.

Este estudo avaliou diferenças nas assembleias de peixes existentes a montante e a jusante dois tipos de bueiros, um em cada um de dois diferentes riachos Neotropicais. A composição e a estrutura da ictiofauna foram avaliadas e seus possíveis padrões espaciais. As amostragens para a ictiofauna foram realizadas mensalmente, entre novembro de 2009 e outubro de 2010, com diversos apetrechos de pesca. Durante o período foram coletados 2.220 indivíduos, sendo 901 peixes nos trechos do riacho Lopeí - bueiro circular e 1.310 peixes nos trechos do riacho Pindorama - bueiro quadrado, pertencentes a 33 espécies. As capturas foram similares nos trechos de montante e jusante no bueiro circular, enquanto que para o bueiro quadrado a abundância de peixes foi um pouco superior no trecho a montante em relação à jusante. Os Characiformes predominaram no trecho a montante de ambos os bueiros. Por outro lado, os Siluriformes foram abundantes no trecho a jusante do bueiro circular, com abundâncias similares entre os trechos do bueiro quadrado. A riqueza e a diversidade de espécies diferiram entre os trechos do bueiro circular (maior valor a jusante), enquanto que os valores foram similares para os trechos do bueiro quadrado. As espécies mais abundantes foram Astyanax altiparanae, A. paranae, A. fasciatus, Ancistrus sp. e Hypostomus sp., porém com diferenças constatadas na ocorrência das duas últimas espécies: estas foram mais abundantes a jusante do bueiro circular, e similares nos trechos do bueiro quadrado. As variações na abundância, riqueza e diversidade constatadas

\footnotetext{
${ }^{1}$ Universidade Estadual do Oeste do Paraná - UNIOESTE, Grupo de Pesquisas em Tecnologia de Produção e Conservação de Recursos Pesqueiros e Hídricos (GETECH). Rua da Faculdade, 645. Jardim Santa Maria. 85903-000 Toledo, PR, Brazil. zico_mariano@hotmail.com (JRM); layne_fernandes@hotmail.com (EFC)

${ }^{2}$ Universidade Estadual do Oeste do Paraná - UNIOESTE, GETECH. Programa de Pós-Graduação em Recursos Pesqueiros e Engenharia de Pesca. Rua da Faculdade, 645. Jardim Santa Maria. 85903-000 Toledo, PR, Brazil. mmakrakis@terra.com.br (MCM); makrakis@terra.com.br(SM)

${ }^{3}$ Universidade Estadual de Mato Grosso do Sul - Grupo de Estudos em Ciências Ambientais e Educação (GEAMBE), BR 163 km 20,2; Mundo Novo, Mato Grosso do Sul. PNPD - PREP/CAPES, GETECH/UNIOESTE, Rua da Faculdade, 645. Jardim Santa Maria. 85903000 Toledo, PR, Brazil. elainealk@yahoo.com.br (EALK)
} 
entre trechos a montante e a jusante, em particular do bueiro circular no riacho Lopeí, sugerindo que os movimentos de peixes são restritos de forma mais intensa neste bueiro, especialmente para Siluriformes. A queda de água na saída do bueiro circular provavelmente cria barreira à passagem dos peixes, especialmente para aqueles peixes que não tem capacidade de saltar, onde a erosão a jusante pode levar a empoleiramento. Estudos sobre projetos de bueiro ou instalações apropriadas são fundamentais considerando que a melhoria destas estruturas pode restaurar a conectividade de populações e comunidades de peixes em riachos.

Key words: Fish passage, Fish population, Habitat fragmentation, Road crossings.

\section{Introduction}

In South America, knowledge of the stream ichthyofauna is poor as a consequence of the large number of species, small number of taxonomists, and mainly sampling complexity due to the geographic diversity of sites, as well as the selectivity of capture devices. This geographic diversity is characterized by linear lotic environments, continuous and unidirectional water flow, habitat variations, and unstable stream beds (Uieda \& Castro, 1999), exhibiting environmental heterogeneity (Bührnheim, 2002), such as shallow and deep stretches, waterfalls, rapids, backwaters, exposed or shaded areas, and sandy or muddy substrate (Fitzpatrick et al., 1998).

Variations in habitat diversity and physicochemical characteristics make streams susceptible to changes, affecting the distribution of the aquatic fauna, as well as the structure of fish assemblages. Moreover, these conditions are favorable for the initial development of eggs, larvae and juvenile, providing them with food and shelter, which are essential for preservation and maintenance of species (Nakatani et al., 2001).

River ecosystems and adjacent areas depend strongly on each other, and the slightest modification (natural or anthropic) in processes related to this relationship may lead to drastic changes in biotic and abiotic dynamics (Naiman et al., 2005). Changes are intensified by human activities, caused by dam construction, improper land use, removal of riparian forest, industrial expansion, and discharge of effluents that change physical and chemical characteristics of the water, water quality, and sediment distribution (Callisto et al., 2002; Corgosinho et al., 2004; Tundisi \& Tundisi, 2008). Urbanization also results in increased road density and, consequently, in an increase in the number of streams crossed by roads (Wheeler et al., 2005), which may lead to severe impacts, such as habitat destruction resulting from the implementation of poorly designed culverts. These structures canalize water from upstream and transpose it downstream; they can be circular or box-shaped, varying in size, length, slope, and quantity, according to DNIT (2004a, 2004b, 2006).

Several culverts may have drops inlet and outlet, hanging culverts; $90 \%$ of them are found in first or second order streams, reducing fish movements between upstream and downstream stretches (Park et al., 2008). They may alter the water flow and also reduce the transversal area and channel depth, resulting in an increase in water velocity and turbulence (Metsker, 1970) in stretches where the water flow is frequently contrary to the ichthyofauna's needs (McKinley \& Webb, 1956). In recent years, biologists and engineers in recognition the problems from decades past on population of salmon have designed and installed culverts that have little effect on fish, and several state fish and wildlife agencies in Califomia, Oregon and Washington, USA (i.e. CDFG, 2002; WDFW, 2003; ODFW, 2004) have published design criteria to minimize the occurrence of adverse conditions that block migratory fish (Kemp \& Williams, 2008).

Conditions imposed by culverts may restrict the ascending and descending movements of fish (Zrinji \& Bender, 1995), preventing them from reaching important areas for reproduction, such as small streams, channels, and floodplain areas (Katopodis, 1993). The implementation of a culvert can cause habitat disruption and changes in patterns of species migration and dispersal, reducing biodiversity over time and favoring fragmentation, which could lead to extinctions (Formam \& Alexander, 1998).

In the past few years, several studies have been carried out in Neotropical streams to describe the composition and structure of fish assemblages, most of them in Brazil streams such as Uieda (1984), Garutti (1988), Agostinho \& Penczak (1995), Abes \& Agostinho (2001), Pavanelli \& Caramaschi (2003), Castro et al. (2004), Cunico et al. (2006), and Perez Jr. \& Garavello (2007). However, there are no studies that assessed the influence of culverts on the ichthyofauna of Neotropical streams in despite of several studies conducted in the other regions, such as those carried out by McKinley \& Webb (1956), Metsker (1970), Katopodis et al. (1978), Dane (1978), Zrinji \& Bender (1995), Forman \& Alexander (1998), Wheeler et al. (2005), Hotchkiss \& Frei (2007), Foltz et al. (2008), Morrison et al. (2009), Nislow et al. (2011), and others.

The poorly constructed culverts may alter structural characteristics of streams, fragment habitats (Formam \& Alexander, 1998; Langill \& Zamora, 2002; Gibson et al., 2005; Park et al., 2008; Benton et al., 2008), and affect fish movement through them. Thus, this study was designed to see if differences in fish assemblages existing upstream and downstream two types of culverts, one on each of two different Neotropical streams. Any differences in fish assemblages were hypothesized to result from changes in fish passage through culverts. However, the actual passage through the culverts was not tested.

\section{Material and Methods}

\section{Study area}

Sampling was carried out in the two streams: Pindorama and Lopeí; both are second order streams and tributaries of 
the São Francisco Verdadeiro River (Fig. 1), Paraná River Basin, southern Brazil.

These streams were chosen because they have two distinct type of drains along their course where each intercepts with roads: OT-525 (Pindorama stream) close to the district of Bom Princípio - PR (city of Toledo) and BR317 (Lopeí stream), between the cities of Toledo and Ouro Verde - PR. In both streams the culverts are multiple (triple): box in the Pindorama stream and circular in the Lopeí stream (Fig 2). The characteristics of culvert engineering are presented in Table 1.

In these areas, stretches of 200 meters were standardized, above (upstream) and below (downstream) of the culvert, totaling 400 meters of sampling in each stream (Fig. 3), a procedure modified from Burford et al. (2009).

\section{Data collection}

Fish collection was conducted monthly from November 2009 to October 2010. Several fishing gears were used for fish catching at specific times. The gears used were rods, sieves, gill nets, and cast nets, as these devices have different selectivity (Uieda \& Castro, 1999), and also to assure sampling in all environments, since the stream is stratified and has pools, currents, and runs. Details of the description of the sample design are in Celestino et al. (2012).

A cast net, with a mesh of $1.5 \mathrm{~cm}$ and an area of $12 \mathrm{~m}$, was cast 20 times at 11 a.m. and 10 p.m. Two rectangular sieves, with metallic frames of $1.2 \times 0.80 \mathrm{~m}$ and netting meshes of 0.5 $\mathrm{cm}$, were cast 20 times at 7 a.m. and 6 p.m., mainly in locals with marginal vegetation. A hook-and-line with live bait was also operated by two samplers at the streams' margins for 30 minutes at 10 a.m., 3 p.m. and 7 p.m. Lastly, a gill net, with an area totaling $28.55 \mathrm{~m}^{2}$ and a mesh varying in distance (2.5, 3,4 , and $5 \mathrm{~cm}$ ) between nonadjacent knots, was exposed for 24 hours, with periodic inspections every 8 hours. Each sampling event's length of time and use of equipment were standardized.

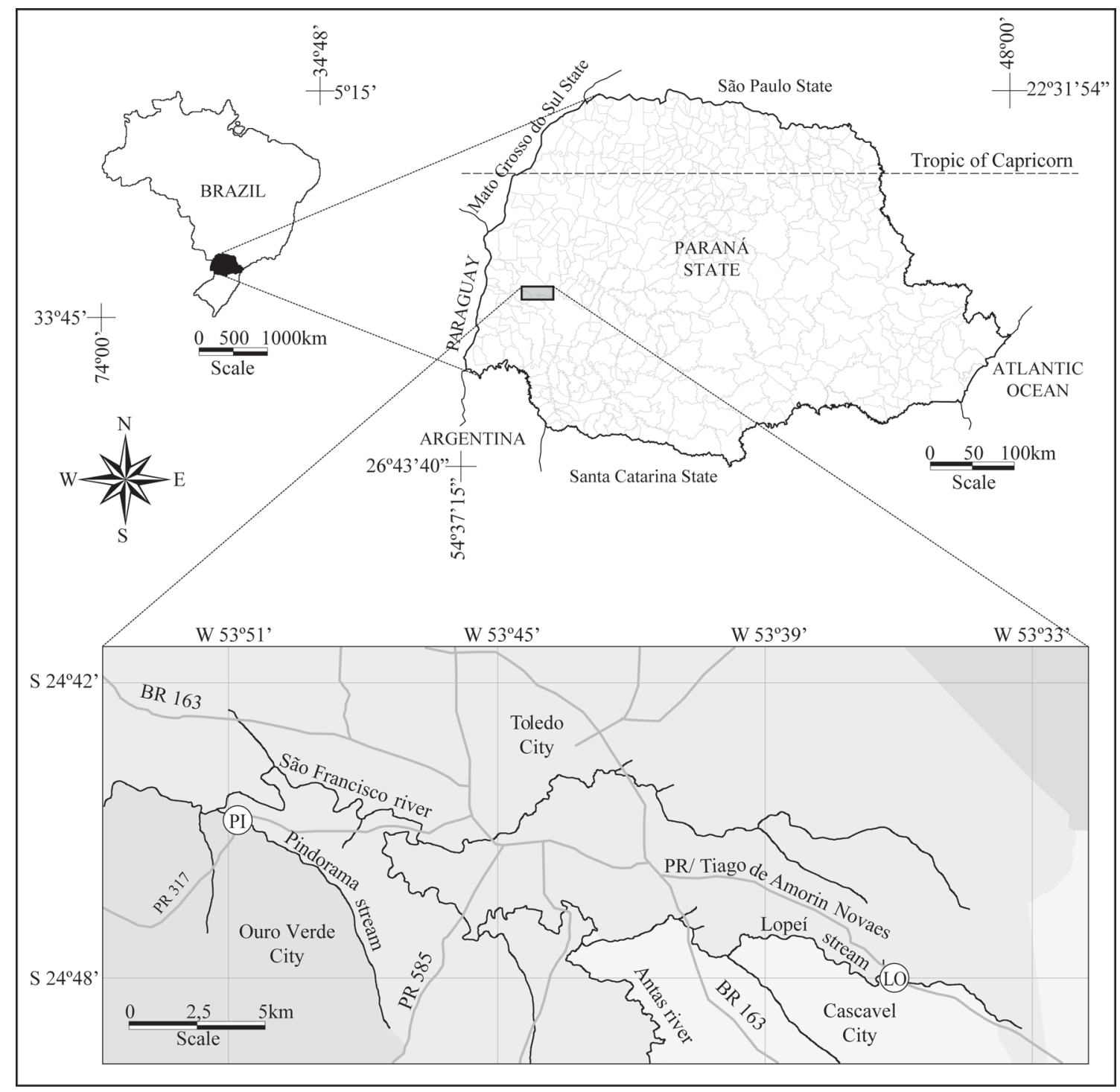

Fig. 1. Sampling sites in the Pindorama (PI) and Lopei (LO) streams, Paraná State, Brazil. 

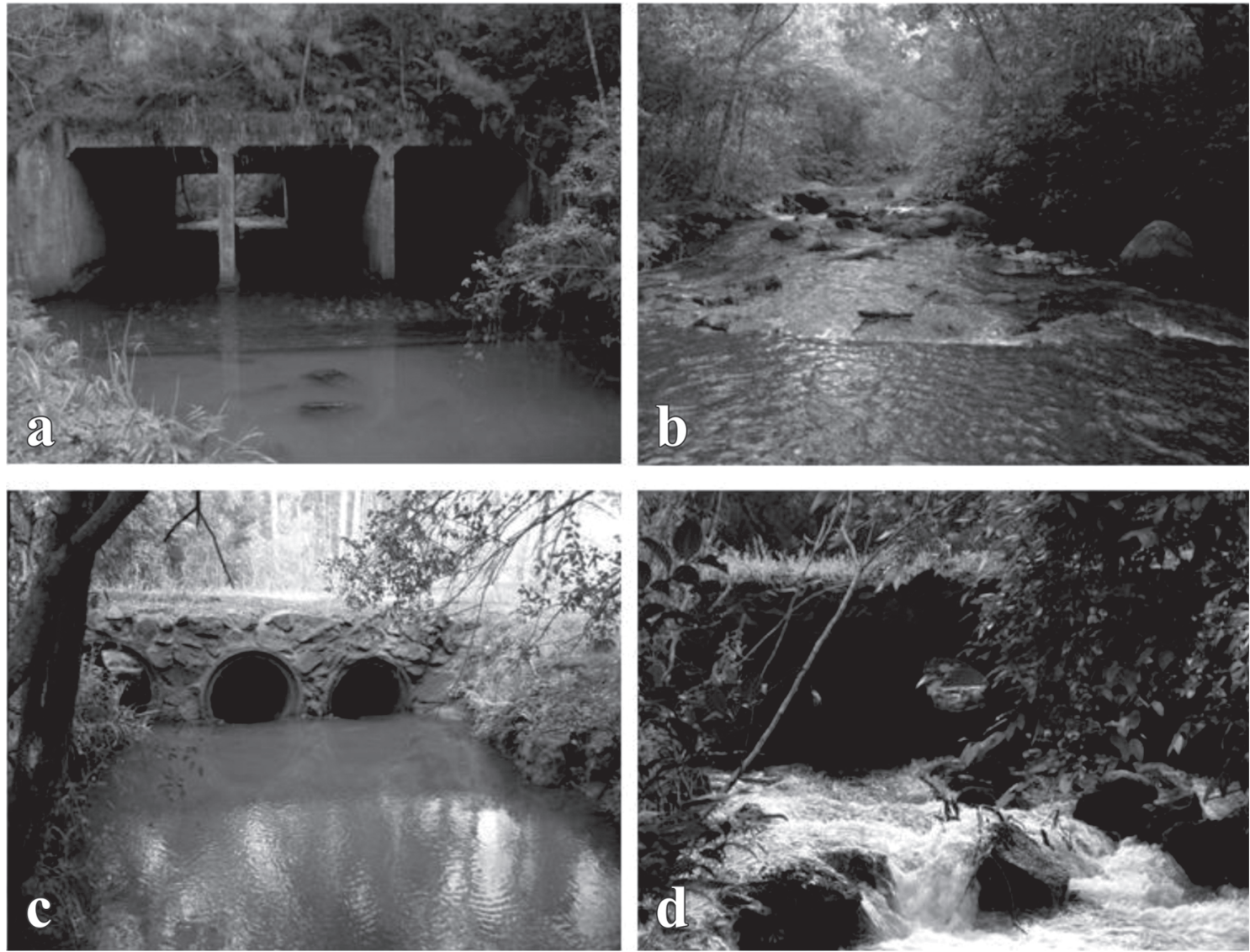

Fig. 2. Sampled stretches: Pindorama stream: a) upstream and b) downstream from box culvert, and Lopeí stream: c) upstream and d) downstream from circular culvert.

The collected fishes were euthanized by benzocaine at a concentration of $250 \mathrm{mg} / \mathrm{l}$ per 10 minute of exposure, according to the approved protocol of the Ethics Committee in Animal Experimentation and the practical classes of Unioeste Protocol $\mathrm{n}^{\mathrm{o}}$ 4109. The specimens were then fixed in formaldehyde $10 \%$, and identified following Graça \& Pavanelli (2007).

For each specimen, data on the standard length $(\mathrm{cm})$ and the total weight (with a precision of $0.1 \mathrm{~g}$ ) were recorded, and the voucher specimens were deposited in the collection of the Museu de Ictiologia do Nupélia, Universidade Estadual de Maringá, Paraná State, Brazil.

Sampling area was calculated based on the distance and average width of each stream stretch. To calculate the average width, stretches were divided in plots of $10 \mathrm{~m}$. In each plot, three measurements were taken to calculate the average width.

\section{Data analysis}

The composition of fish species, families, and orders of each stretch sampled in the streams was analyzed. The index of constancy (C) (Dajoz, 1978) was used to determine which species were constant at a given time scale, using the formula $\mathrm{C}=\mathrm{n} / \mathrm{N} * 100$, where: $\mathrm{n}=$ number of catches in which the species was captured, and $\mathrm{N}=$ total number of catches carried out in the sampled stretches. Values were categorized following Dajoz (1978) as: constant $=\mathrm{C}>50 \%$, accessory $=$ $25 \%>\mathrm{C}<50 \%$, and accidental $=\mathrm{C}<25 \%$.

Table 1. Characteristics of study area. $\mathrm{SH}=$ Shape of the culverts, $\mathrm{C}=$ circular, $\mathrm{B}=$ box, Year $=$ year of the roads construction, $\mathrm{CA}=$ cross-section area, $\mathrm{U}=$ upstream and $\mathrm{D}=$ downstream areas of culverts, $\mathrm{LC}=$ length of culverts, $\mathrm{V}=$ mean flow velocity $(\mathrm{V}), \mathrm{DF}=$ mean depth of flow, $\mathrm{S}=$ slope, $\mathrm{OP}=$ outlet perch.

\begin{tabular}{|c|c|c|c|c|c|c|c|c|c|c|c|c|}
\hline \multirow[b]{2}{*}{ Streams } & \multirow{2}{*}{ Latitude } & \multirow{2}{*}{ Longitude } & \multirow{2}{*}{ SH } & \multirow[b]{2}{*}{ Year } & \multirow{2}{*}{$\begin{array}{l}\text { CA } \\
\left(\mathrm{m}^{2}\right)\end{array}$} & \multicolumn{2}{|c|}{ Area $\left(\mathrm{m}^{2}\right)$} & \multirow{2}{*}{$\begin{array}{l}\mathrm{LC} \\
(\mathrm{m})\end{array}$} & \multirow{2}{*}{$\begin{array}{c}\mathrm{V} \\
(\mathrm{m} / \mathrm{s})\end{array}$} & \multirow{2}{*}{$\begin{array}{l}\mathrm{DF} \\
\mathrm{cm}\end{array}$} & \multirow{2}{*}{$\begin{array}{c}\mathrm{S} \\
(\%)\end{array}$} & \multirow{2}{*}{$\begin{array}{c}\mathrm{OP} \\
(\mathrm{cm})\end{array}$} \\
\hline & & & & & & $\mathrm{U}$ & $\mathrm{D}$ & & & & & \\
\hline Lopeí & $24^{\circ} 47^{\prime} 47.6^{\prime \prime} \mathrm{S}$ & $53^{\circ} 36^{\prime} 17.1^{\prime \prime} \mathrm{W}$ & $\mathrm{C}$ & 1995 & 1.17 & 908 & 1124 & 7.0 & 0.97 & 16.0 & 1.86 & 40.0 \\
\hline Pindorama & $24^{\circ} 44^{\prime} 44.6^{\prime \prime} \mathrm{S}$ & $53^{\circ} 50^{\prime} 48.5^{\prime \prime} \mathrm{W}$ & B & 1979 & 9.30 & 1180 & 1386 & 26.6 & 1.56 & 9.3 & 1.09 & 15.0 \\
\hline
\end{tabular}




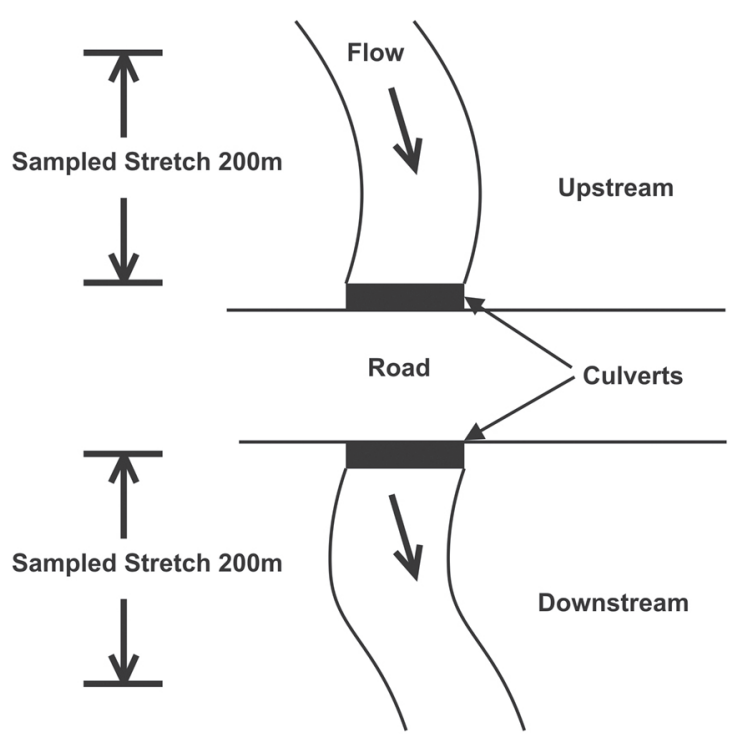

Fig. 3. Diagram showing the design of fish sampling in the streams.

To evaluate the mean standard length of fish between the sampled streams and the stretches of different culverts were used the one-way ANOVA to test for differences.

To analyze the species composition and the temporalspatial relative abundance (number of individuals square-root transformed) (Magurran, 1988; Winemiller, 1996) of the fish assemblage in each stretch (upstream and downstream) and sampling month, a data matrix was built (using number and biomass of individuals, square-root transformed). This data matrix was used to calculate community parameters, such as species abundance, richness $(S)$ (Magurran, 1988), species diversity ( $H$ 'Shannon-Weiner), and evenness $(E)$ for each stretch (upstream and downstream) and type of culvert (factors). Two-way ANOVAs were used to test for differences.

The pattern of temporal persistence was assessed as the frequency of occurrence of each species in the catches (y), plotted against the logarithm of the mean abundance (x) (Winemiller, 1996). Spatial aggregation was assessed with a linear regression between the logarithm of the mean abundance (x) and the logarithm of the variance (y) (Taylor, 1961; Maurer, 1994).

For analyzing the structure of the fish community we used the capture matrix in absolute values, which were square-root transformed to avoid a bias caused by very abundant species (Winemiller, 1996). Next, the data matrix of the fish assemblage was used in a Correspondence Analysis (CA) (Gauch Jr., 1986; Ludwing \& Reinolds, 1988). To test for the significance of the relationships observed, a Kruskal Wallis test was applied on the axis 1 .

Normality and homogeneity were tested using data of community parameters and the axis 1 generated by the CA. Statistical analyses were performed in Statistica 7.0. The significance level used was $p<0.05$.

\section{Results}

During the study period, 2,220 fish were collected; 901 in the Lopeí stream - circular culvert (412 in the upstream and 489 in the downstream stretch) and 1,319 in the Pindorama stream - box culvert (721 in the upstream and 598 in the downstream stretch). These fish belong to five orders and 11 families (Table 2). A total of 33 species were sampled; 27 species occurred in the Lopeí stream (18 in the upstream and 22 in the downstream stretch of the circular culvert), and 25 species occurred in the Pindorama stream (20 in the upstream and 19 in the downstream stretch of the box culvert).

The orders Characiformes and Siluriformes had the largest numbers of families, $36.4 \%$ each (Fig. 4a). The Characiformes were more frequent in the upstream stretches of both culverts (Fig. 4b). Differences were observed for the Siluriformes between stretches of the circular culvert, with a larger number of catches in the downstream stretch. However, catches were similar for this order between stretches of the box culvert (Fig. 4b).

The most common families (Fig. 5a) were Loricaridae (11 species) and Characidae (7 species). The tendency in differences between stretches of the culverts observed for Characiformes and Siluriformes was also observed for these two families (Fig. 5b).

Among the captured species, $66 \%$ are small (smaller than $10 \mathrm{~cm}$ in standard length). The evaluation of the mean standard length of fish between stretches of different culverts showed that larger fish were caught in both stretches (upstream and downstream) of the Lopeí stream - circular culvert (Fig. 6), but this difference was not significant. The difference between stretches was also not significant for the Pindorama stream box culvert.

Eight species were common to both streams, five species were exclusive of the Pindorama stream - box culvert, and eight species were exclusive of the Lopeí stream - circular culvert.

In the upstream stretch of the Lopeí stream (circular culvert), there was a low number of constant species (11\%), $1 \%$ of accessory species, $23 \%$ of accidental species, and $52 \%$ of absent species. In the downstream stretch of this stream, $17 \%$ of the species were constant, $1 \%$ accessory, $38 \%$ accidental, and $32 \%$ absent. However, in the upstream stretch of the Pindorama stream (box culvert), 26\% of the species were constant, $11 \%$ accessory, $17 \%$ accidental, and $41 \%$ absent. In the downstream stretch of this stream, $23 \%$ of the species were constant, $1 \%$ accessory, $14 \%$ accidental, and $50 \%$ absent (Table 2).

The most abundant species in number and biomass in both stretches in the Lopeí stream - circular culvert were Astyanax fasciatus, A. paranae, A. altiparanae, and Rhamdia quelen, whereas Ancistrus sp. was also abundant in the downstream stretch together with species of Astyanax and R. quelen (Fig. 7). For the stretches in the Pindorama stream box culvert, the high values of number of individuals and biomass were different of the pattern found in the Lopeí stream 


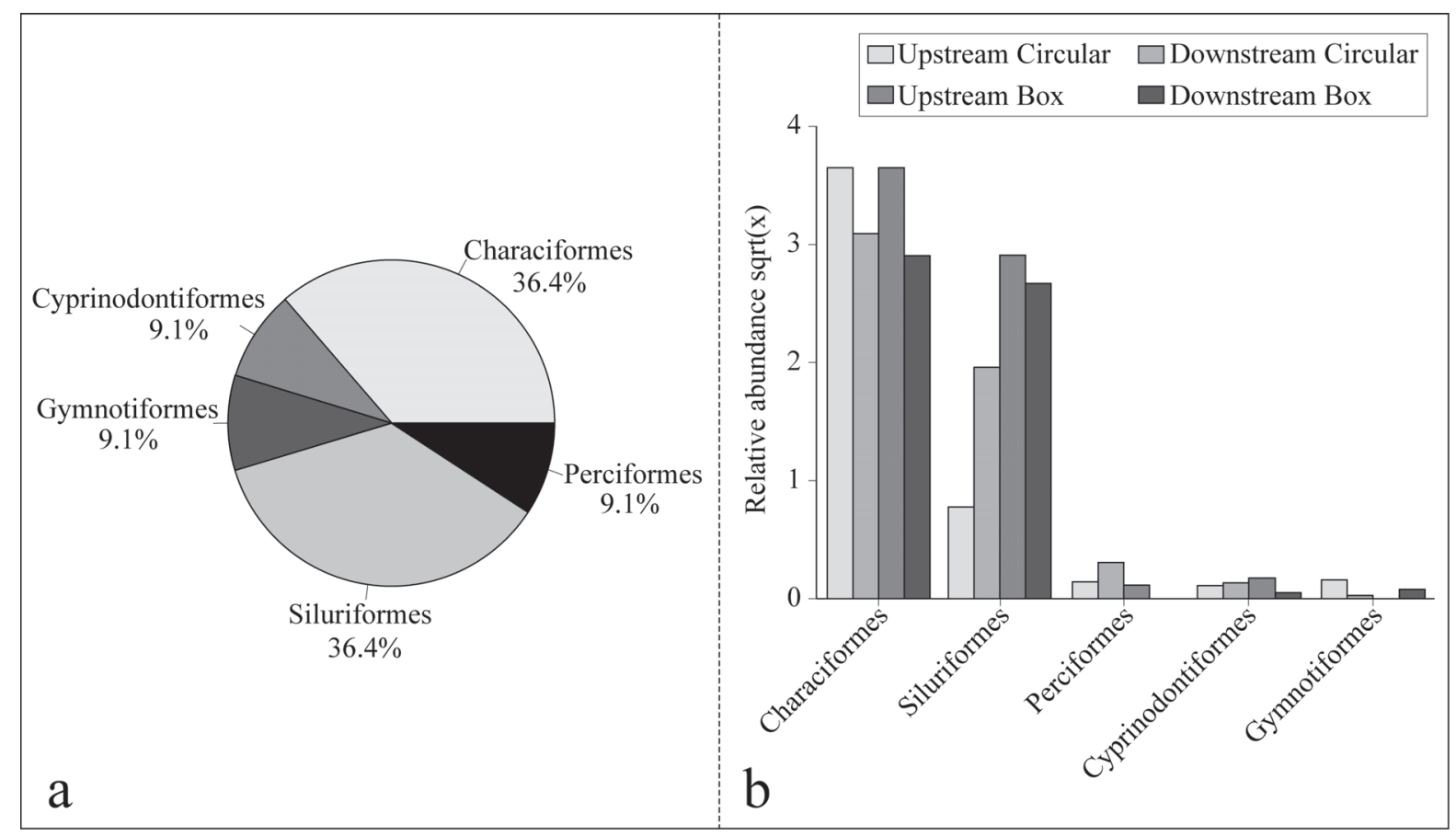

Fig. 4. Relative frequency of number of fish sampled by Order (a), and relative frequency of the number of fish by Order in the sampled stretches of the Lopeí stream - circular culvert and Pindorama stream - box culvert (b).

- circular culvert, considering that in both upstream and downstream stretches Siluriformes such as Ancistrus sp. and Hypostomus sp. were abundant, as well as the 'lambaris', including Heptapterus mustelinus, in the downstream stretch.

Species richness was higher in the stream with a box culvert, Pindorama stream (Fig. 8a), as evidenced by interactions in two-way ANOVA $(\mathrm{F}=4.9551 ; \mathrm{p}=0.031)$, showed different between the upstream and downstream stretches in this stream. In the Lopeí stream - circular culvert, richness was higher in downstream stretch (Fig. 8a). The interaction (two-way ANOVA) between culvert type and stretch $(F=3.0497 ; p=0.087)$ was not significant for evenness

\section{a}

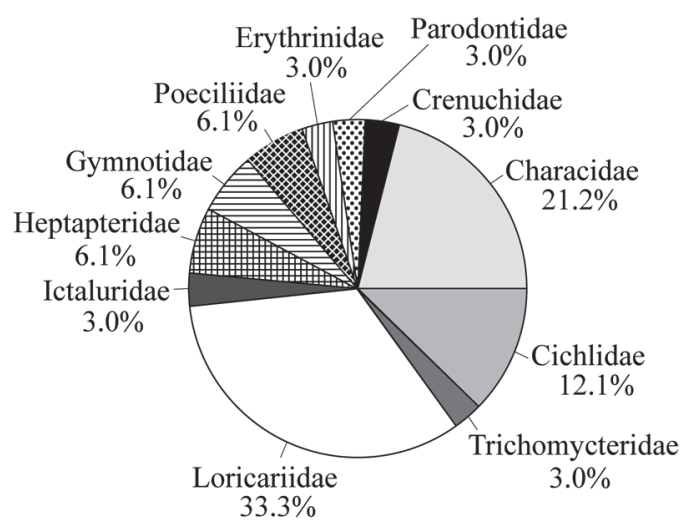

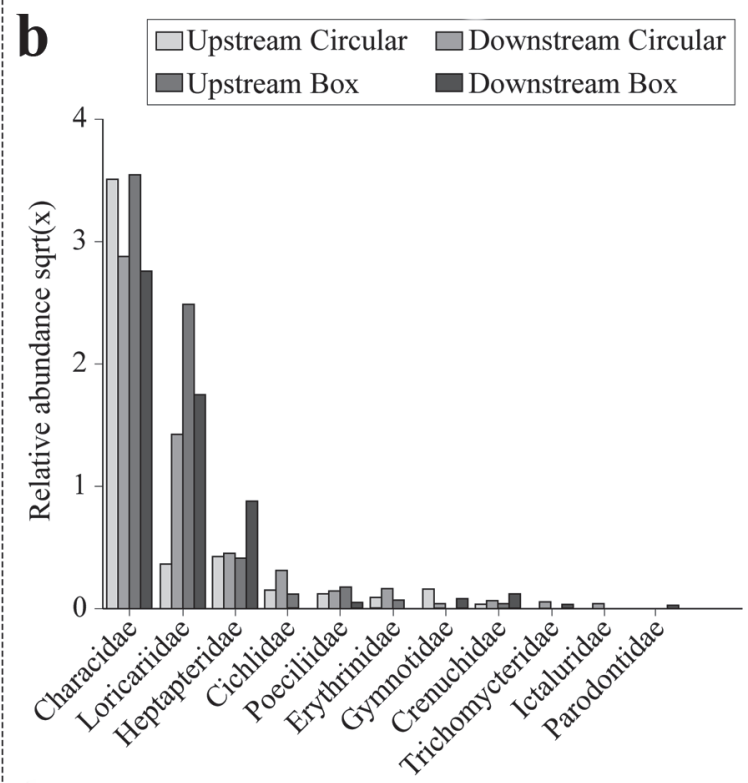

Fig. 5. Relative frequency of number of fish sampled by Family (a), and relative frequency of the number of fish by Family in the sampled stretches of the Lopeí stream - circular culvert and Pindorama stream - box culvert (b). 


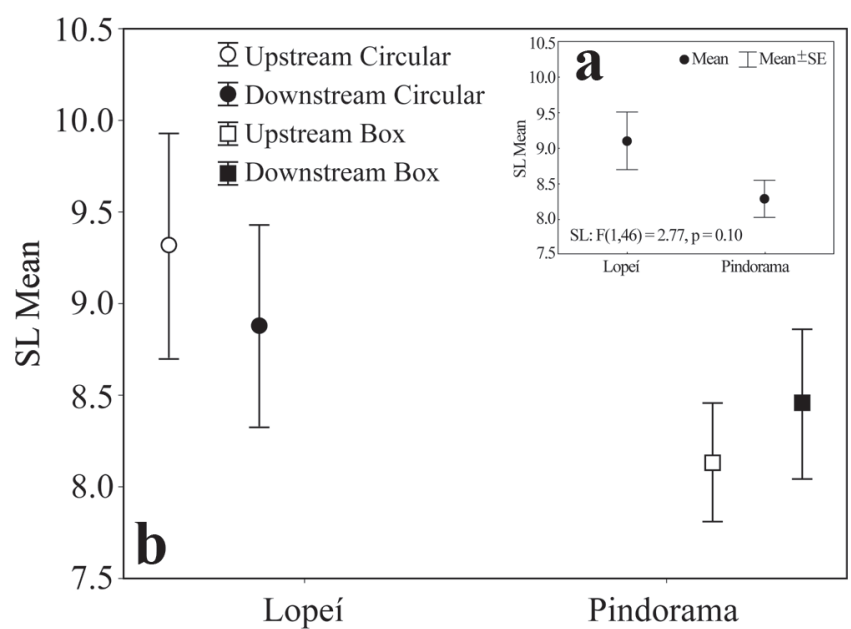

Fig. 6. Standard length of fish (mean \pm standard error) in the Lopeí and Pindorama streams (a), and in the sampled stretches (b) of the Lopeí stream - circular culvert and Pindorama stream - box culvert.

(Fig. 8b). The Shannon-Weiner diversity index $\left(H^{\prime}\right)$ followed that same pattern as species richness (Fig. 8c).

The interaction of two-way ANOVA $(F=10.230, p=0.002)$ among the factors evaluated (culverts and stretches) was significant, indicating differences between the culverts and stretches. The figure $8 \mathrm{c}$ shows the highest values for stream with box culvert and the largest discrepancy is between stretches in the stream with circular culvert.

The correspondence analysis (CA) calculated with data on composition, distribution, and abundance (Fig. 9) was represented in the axes 1 and 2. These axes were chosen based on their eigenvalues; the eigenvalue of axis 1 was 0.20 , whereas the eigenvalue of axis 2 was 0.17 , which is considered as low. Hence, only the axis 1 was retained for statistical analysis and interpretation, following Matthews (1998), who stated that below 0.20 the responses to gradients start to be linear.

The KW test applied on this axis showed spatial dissimilarity between streams with culvert of different shapes $(\mathrm{H}=35.27 ; \mathrm{p}<0.0001)$, and the upstream and downstream stretches of the culverts. The streams with different types of culvert were clearly separated in the axis 1 . This difference may result from the specificity of the fish assemblages of each stream, especially in terms of rare species (Fig. 9).

High abundance occurred in downstream stretch in the Lopeí stream - circular culvert between January and June (Fig. 10a), during the transition period between the rainy and dry season as well as in the dry season. However, the most abundance of fish has been obtained in the stream with a box culvert between December and April, mainly in the upstream stretch (Fig. 10b) during rainy season (high pluviosity).

The analysis of persistence showed that the dominant species in terms of abundance (A. fasciatus, $A$. paranae, and A. altiparanae) were also constant in all samples during the study period, exhibiting higher persistence than other species in all stretches of culverts (Fig. 11). The species with low abundance were also the rarest (less persistent).

The general pattern of aggregation of fish communities in streams with different culverts did not differ from random, and so the community can be characterized as sparsely distributed (Fig. 12). Although fish species were captured several times (see results on persistency), they occurred in low abundance in some months (random pattern).

\section{Discussion}

The effects of culverts on stream fish communities can be difficult to detect, because fish abundance and richness are highly heterogeneous in space and time (Nislow et al., 2011). The abundance observed in the present study, with a larger number of fish in the upstream stretch of the box culvert, contrary to what was observed in the circular culvert, which exhibited lower values, mainly in the upstream stretch, may be explained by the conditions imposed by culverts that restrict the fish movements and habitat occupation. According to Benton et al. (2008), culverts are potential barriers to connectivity and, with rare exceptions, hardly accomplish the function of allowing fish passage, what may affect fish occurrence and relative abundance upstream of culverts.

The predominance of Characiformes, especially Characidae, in upstream and downstream stretches of both culverts suggests that these fish may have higher mobility between their stretches. However, for Siluriformes, mainly Loricaridae, the circular culvert seems to limit habitat occupation, since the most catches occurred in the downstream stretch of this culvert. Nevertheless, the similar values observed between stretches of the box culvert for this fish group suggest that its movements are probably not hindered in this place. Benton et al. (2008) stated that box and circular culverts reduce significantly the movement frequency between upstream and downstream stretches, probably in response to differences in water depth and velocity.

The movement limitation of Siluriformes in relation to Characiformes previously mentioned may also be associated with the swimming capacity of the species. According to Hoffman \& Dunham (2007), the ability of fish to pass through culverts is affected by behavioral and physiological factors and by the physical conditions created by culverts. Studies carried out with Pimelodus maculatus (Siluriformes) showed that this species swims slower (Santos et al., 2006) than species of Characiformes, in the case of species considered as migratory, such as Leporinus reinhardti (Anostomidade) (Santos et al., 2007), and small-sized species, such as Bryconamericus stramineus (Characidae) (Castro et al., 2010). These characteristics can improve the Characiformes' ability to transpose obstacles, such as high water flows, which are frequently found in culverts. On the other hand, the Siluriformes may have difficulty in these obstacles, since their swimming ability is inferior. These differences can 
Table 2. Fish species collected in the stretches of Lopeí (Upstream Circular Culvert - UC, Downstream Circular Culvert - DC) and Pindorama (Upstream Box Culvert - UB, Downstream Box Culvert - DB) streams. SL = mean standard length of fish species $(\mathrm{SL})(\mathrm{cm})$. Rating scales of constancy in color: dark gray (constant), gray (accessory), light gray (accidental), and white (absent). NUP - Museu de Ictiologia do Nupélia, Universidade Estadual de Maringá, Paraná State, Brazil.

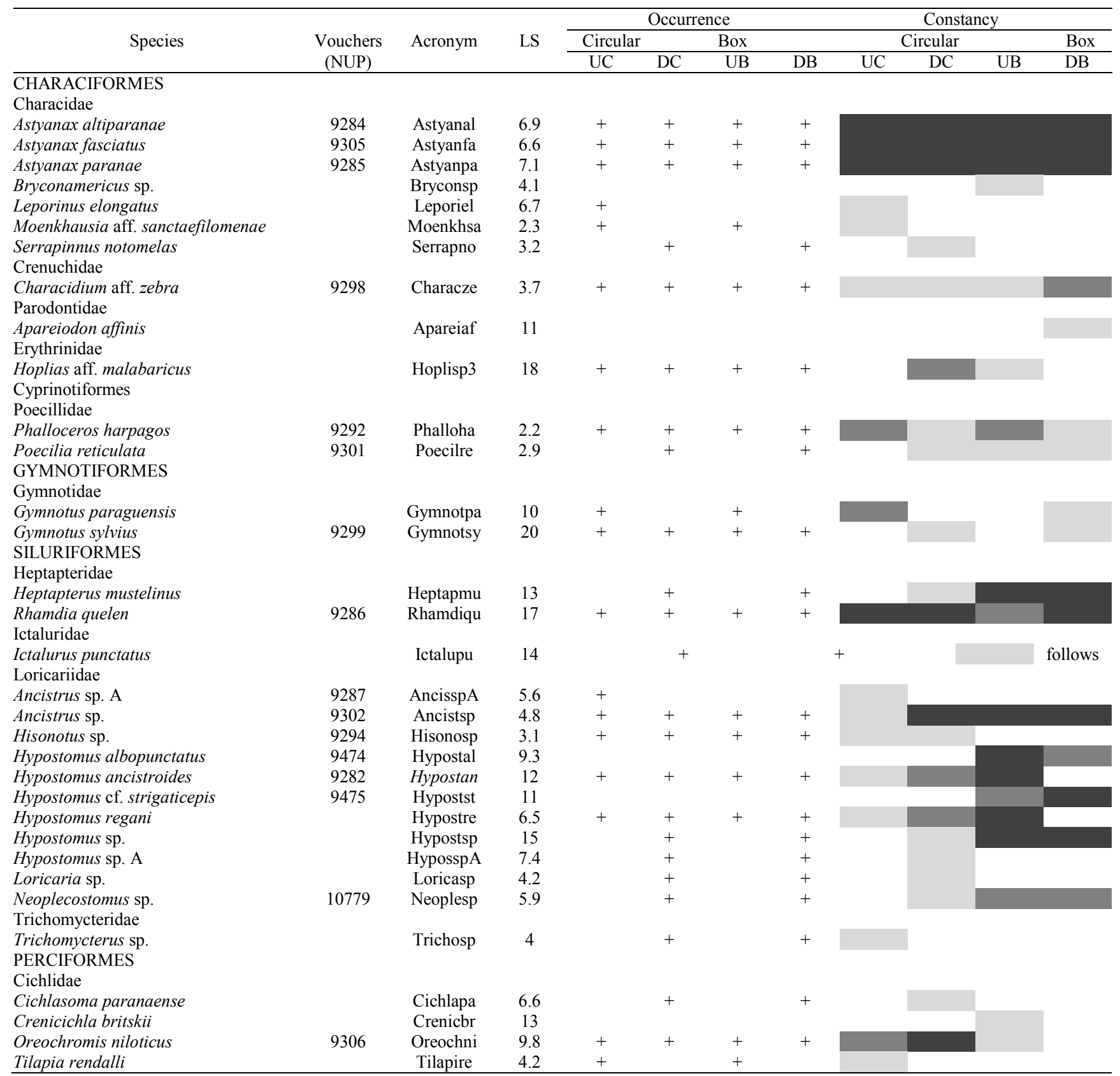

explain the similar abundance of Characiformes in different culverts and stretches, as well as the lower abundance of Siluriformes in the upstream stretch of the circular culvert.

This tendency was evidenced when we analyzed species abundance and constancy. The most abundant species were Astyanax altiparanae, A. paranae, A. fasciatus, Ancistrus sp., and Hypostomus sp., but with differences observed in the occurrence of the last two species: they predominated in the downstream stretch of the circular culvert, and occurred in similar abundance in the stretches of the box culvert. Hence, the effects of culverts on the fish assemblage may vary depending on the species and are related to culvert characteristics, which can make culverts impassable to some fish. 
The streams that have culverts with higher slope increase water velocity and the possibility of forming rungs at the exit of the culvert (Poplar-Jeffers, 2005), what may cause disruption in fish communities. According to the authors, the most common problems observed in culverts are related to the depth of the water column at the entrance and exit, when it is lower than $0.15 \mathrm{~m}$, and to the lack of continuity of substrate along the culvert. In addition, Benton et al. (2008)
Lopeí Upstream (Circular Culvert)

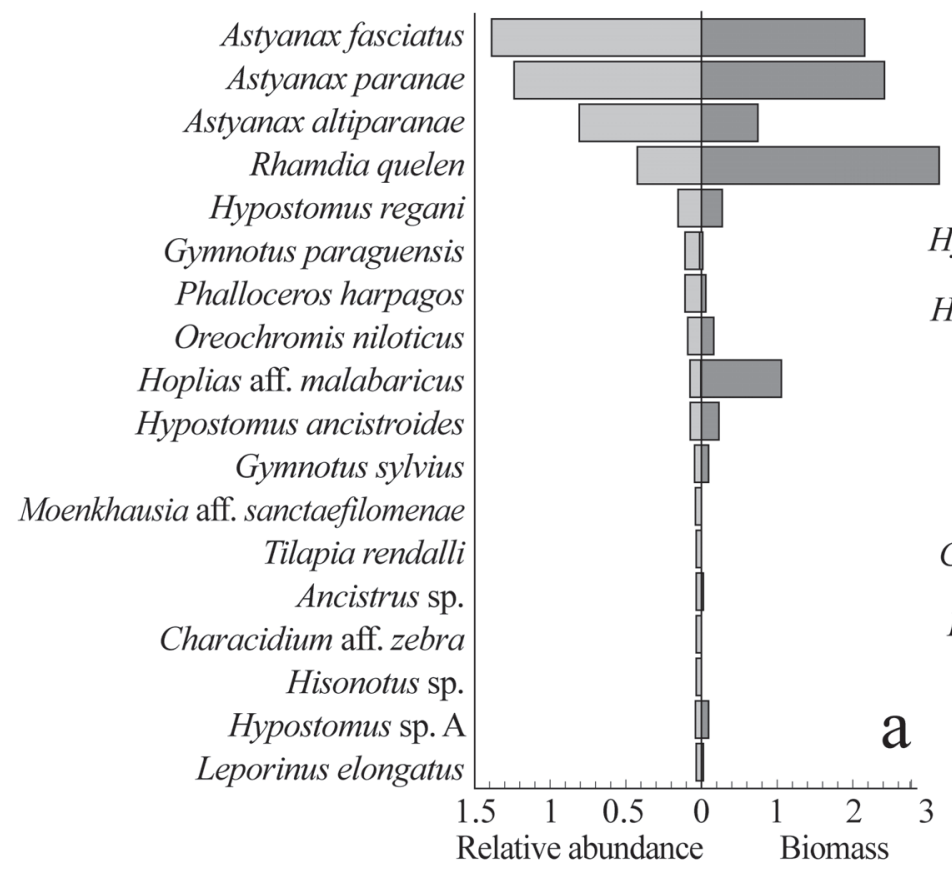

Pindorama Upstream (Box Culvert)

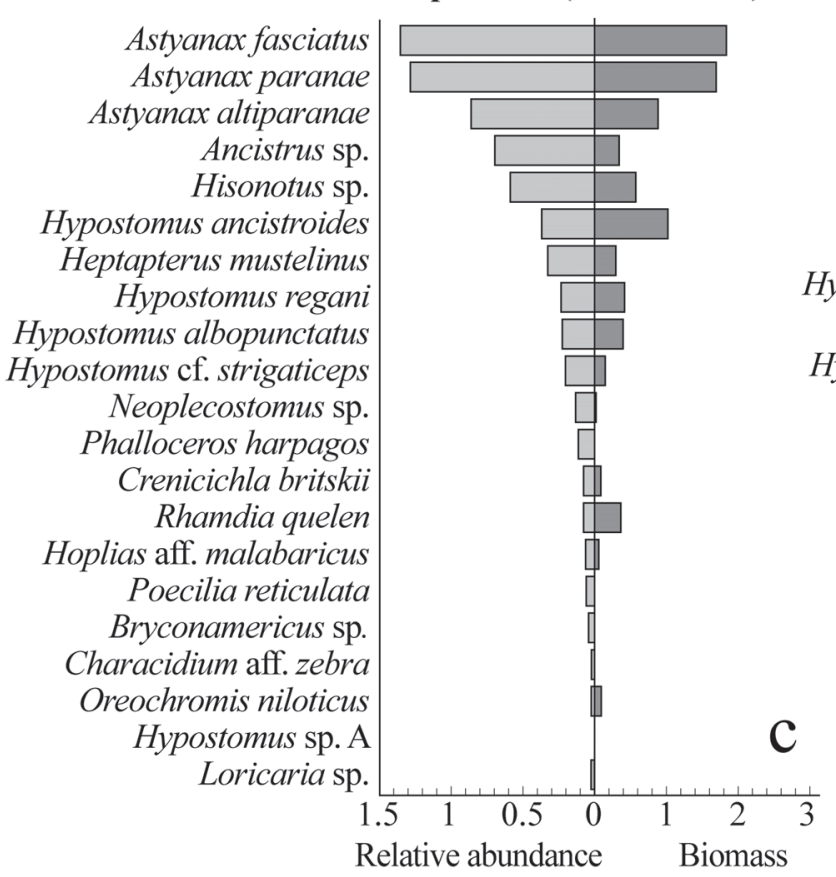

\section{Lopeí Downstream (Circular Culvert)}

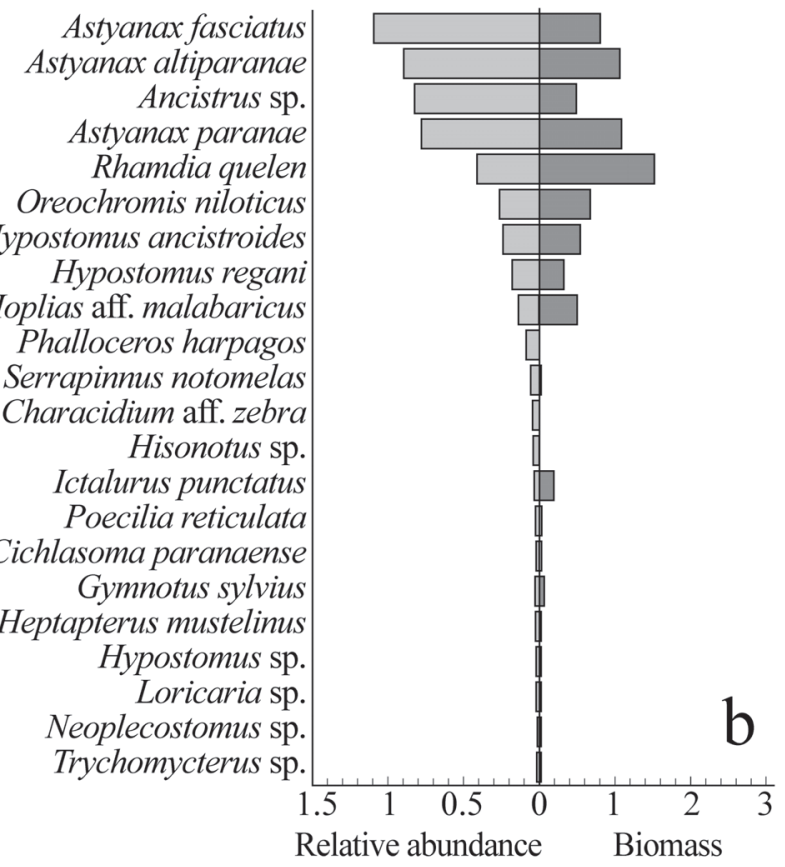

Pindorama Downstream (Box Culvert)

Astyanax fasciatu
Astyanax paranae
Astyanax altiparanae
Ancistrus sp
Hypostomus sp
Rhamdia quelen

Hypostomus albopunctatus

Neoplecostomus sp.

Characidium aff. zebra

Gymnotus sylvius

Hypostomus regani

Ancistrus sp. A

Apareidon affinis

Gymnotus paraguensis

Ictalurus punctatus

Phalloceros harpagos

Poecilia reticulata

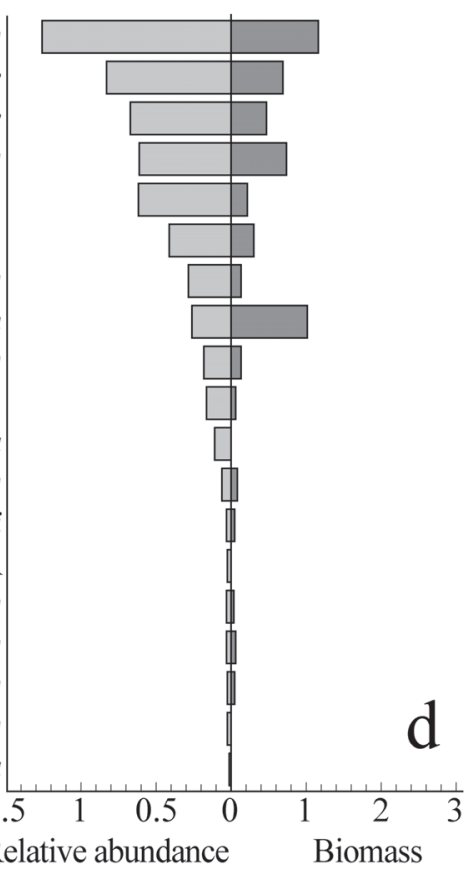

Fig 7. Relative abundance and biomass (square-root transformed) of fish species in the sampled stretches of the Lopeí stream - circular culvert (a - b) and Pindorama stream - box culvert $(\mathbf{c}-\mathbf{d})$. 

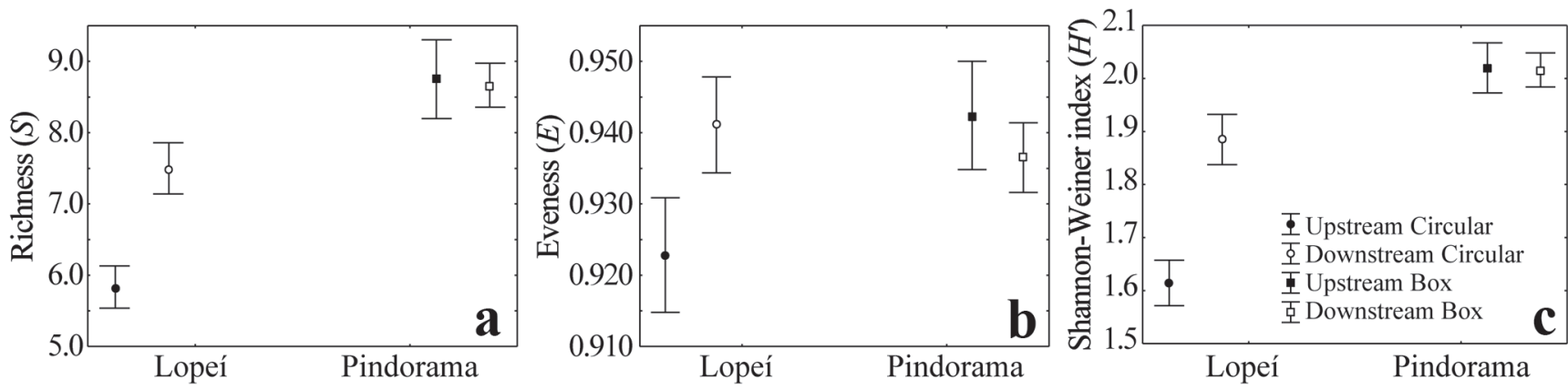

Fig. 8. Species richness $(S)(\mathbf{a})$, evenness $(E)(\mathbf{b})$, and species diversity (Shannon-Weiner Index - H') (c) in the sampled stretches of the Lopeí stream - circular culvert and Pindorama stream - box culvert.

stated that poorly designed culverts may cause direct changes in stream morphology in upstream stretches. According to the British Columbia Ministry of Transportation and Highways (2000), it is fundamental to line up the culvert with the existing channel, in order to minimize changes in the direction of water flow; ponds can also be placed at the entrance and exit of the culvert, and chicanes can be placed inside them, facilitating fish passage. Water velocity should respect the limits of each species (Cahoon et al., 2007), not exceeding $55 \mathrm{~cm} / \mathrm{s}$ (Gardner, 2006). The roughness of the culvert should also be observed as well as the model of the chicanes (Hoffman \& Dunham, 2007).

The loss of natural structural complexity in the substrate and in the water flow is other side effect of stream culverts, as the natural conditions are replaced by the uniformity of a culvert, which alters fish habitats and changes the hydraulic capacity of the channel, usually creating rapids (Dane, 1978). In the present study, box and circular culverts seemed to have different influence on the structuring of upstream and downstream habitats. The most abundant species, $A$. fasciatus, A. paranae, and A. altiparanae prefer habitats such as ponds and backwaters (Langeani et al., 2005), which are present in the four stretches sampled, whereas Heptapterus mustelinus prefers shallow (Becker, 2002) and shady habitats, with rapids and rocky bottom (Dala-Corte et al., 2009), characteristics observed in the downstream stretch of the box culvert, where the abundance of this species was three times higher. According to Tundisi \& Tundisi (2008), changes in natural habitat characteristics can alter the distribution of some species; these changes can be caused by culverts (Forman \& Alexander, 1998).

The culvert length and water flow may lead to differences in species richness between stretches (Poplar-Jeffers, 2005). In this study, although the circular culvert had a shorter length and lower velocity than the box culvert, it seems to have higher impact on the fish assemblage than the box culvert. We observed higher richness and diversity values in the downstream stretch than in the upstream stretch of the circular
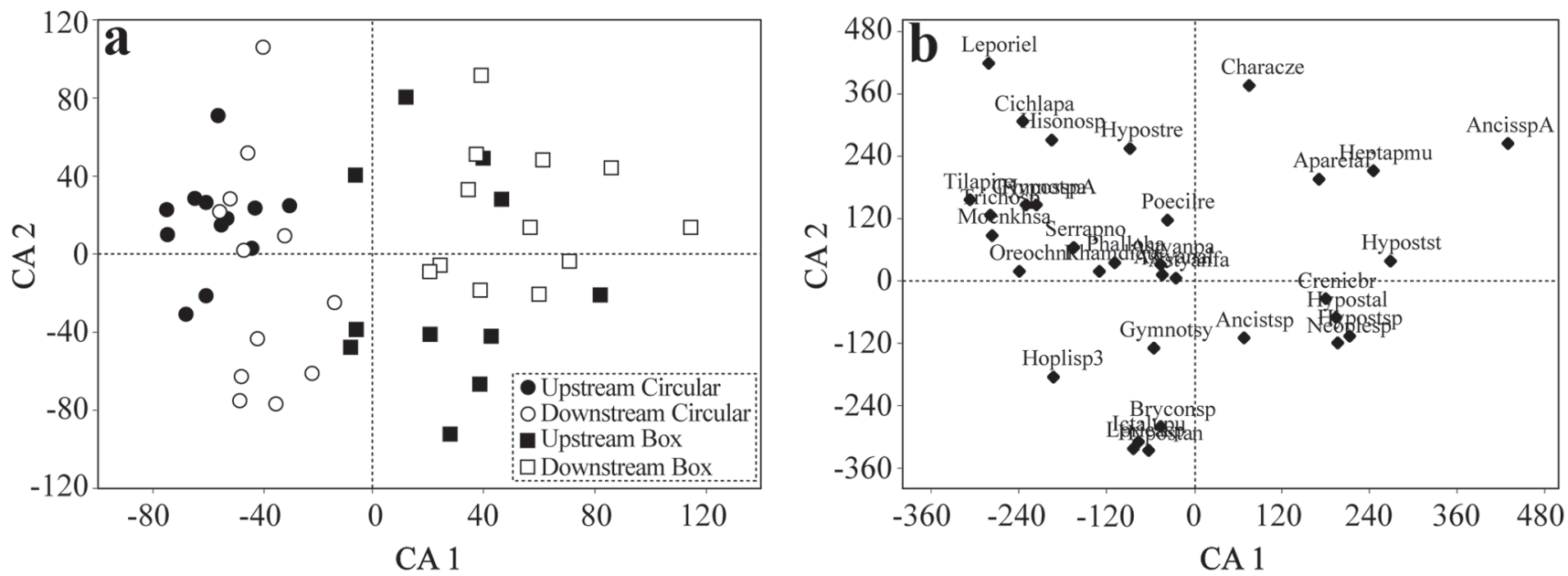

Fig. 9. Results of Correspondence Analysis (CA) between the sampled stretches of the Lopeí stream - circular culvert and Pindorama stream - box culvert (a), and species distribution scores (b). 

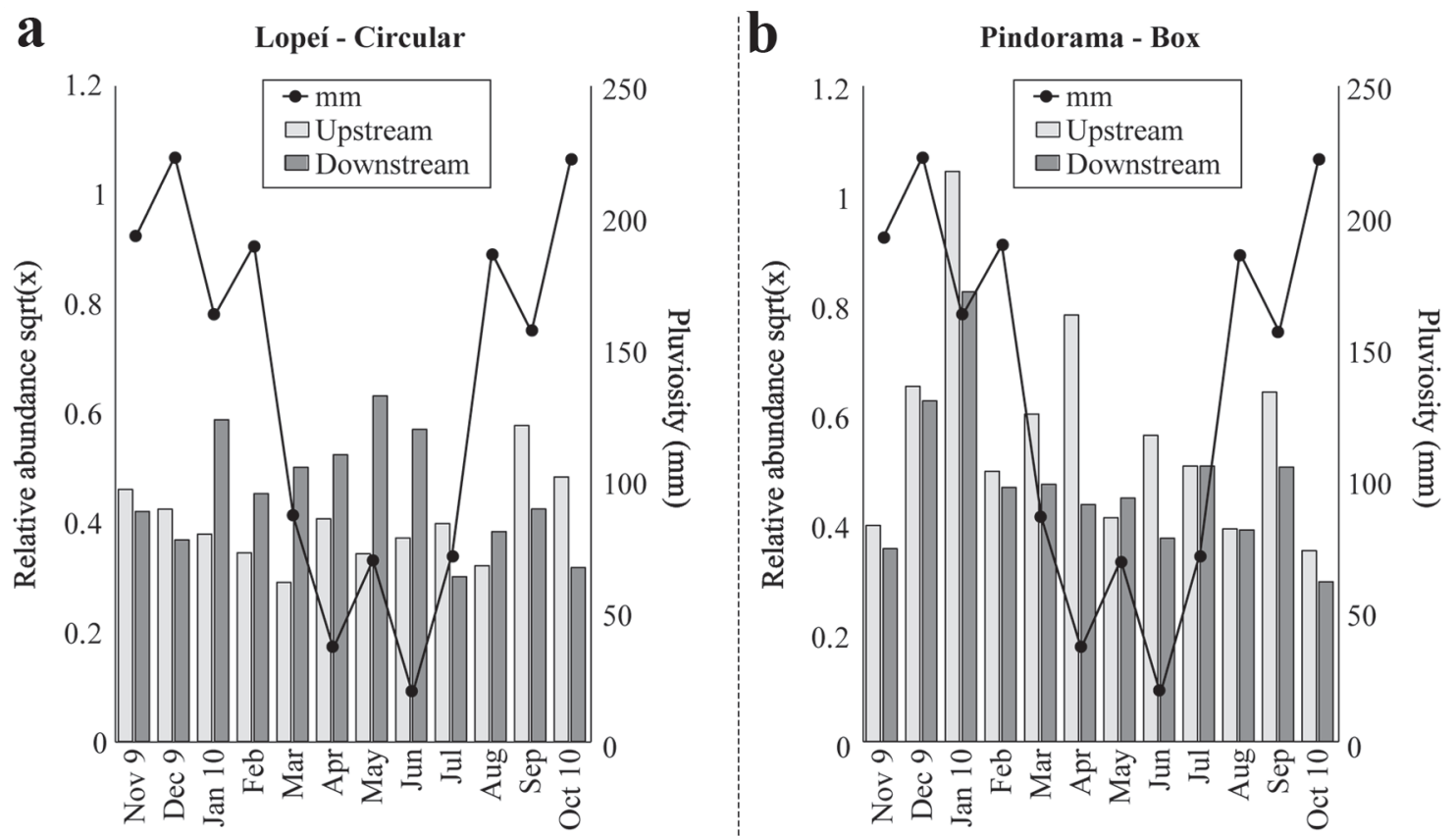

Fig. 10. Temporal pattern of the precipitation and abundance of fish in the sampled stretches of the Lopeí stream - circular culvert (a) and Pindorama stream - box culvert (b).
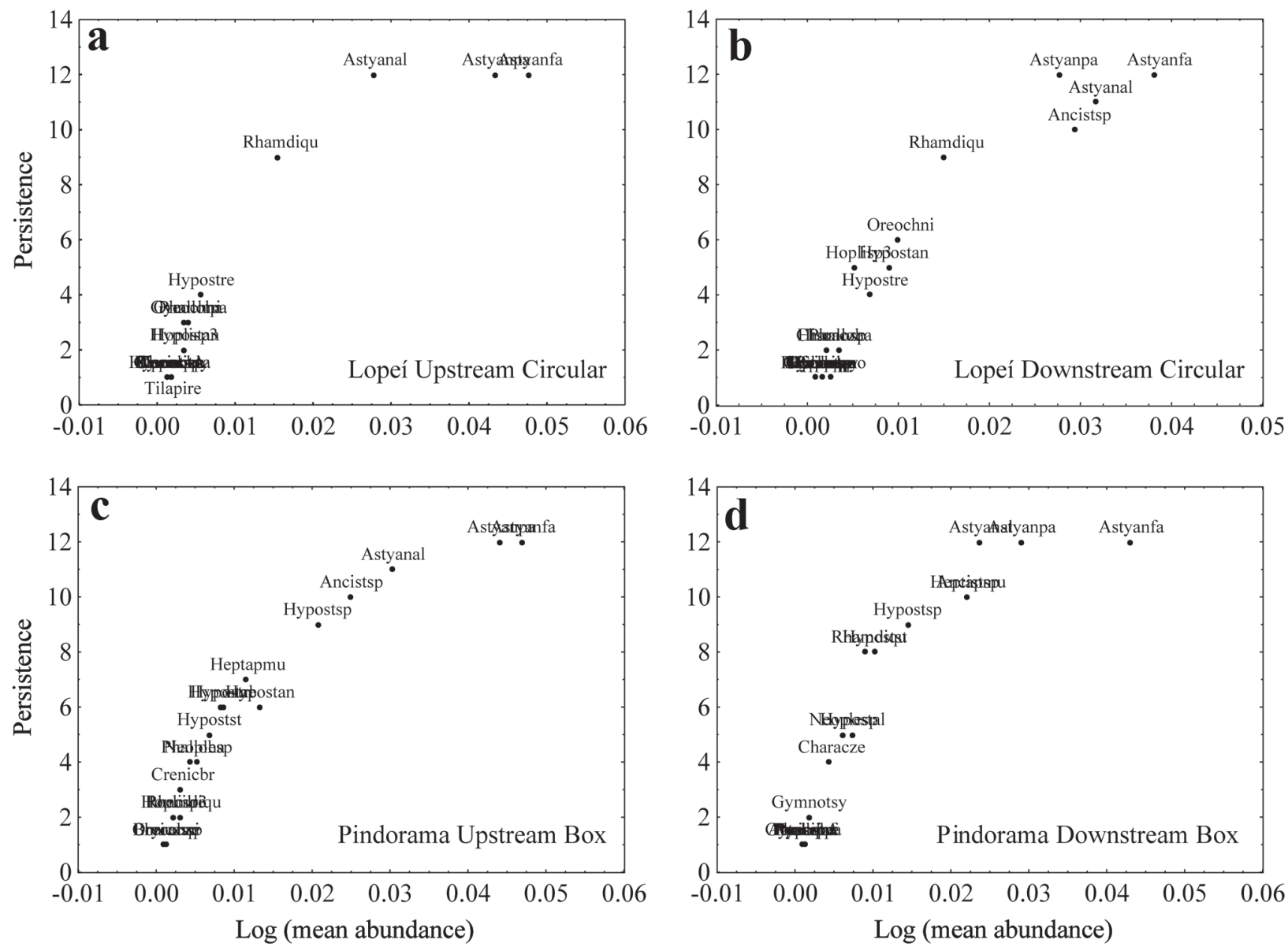

Fig. 11. Temporal persistence of the fish species in the sampled stretches of the Lopeí stream - circular culvert (a - b) and Pindorama stream - box culvert $(\mathbf{c}-\mathbf{d})$. 

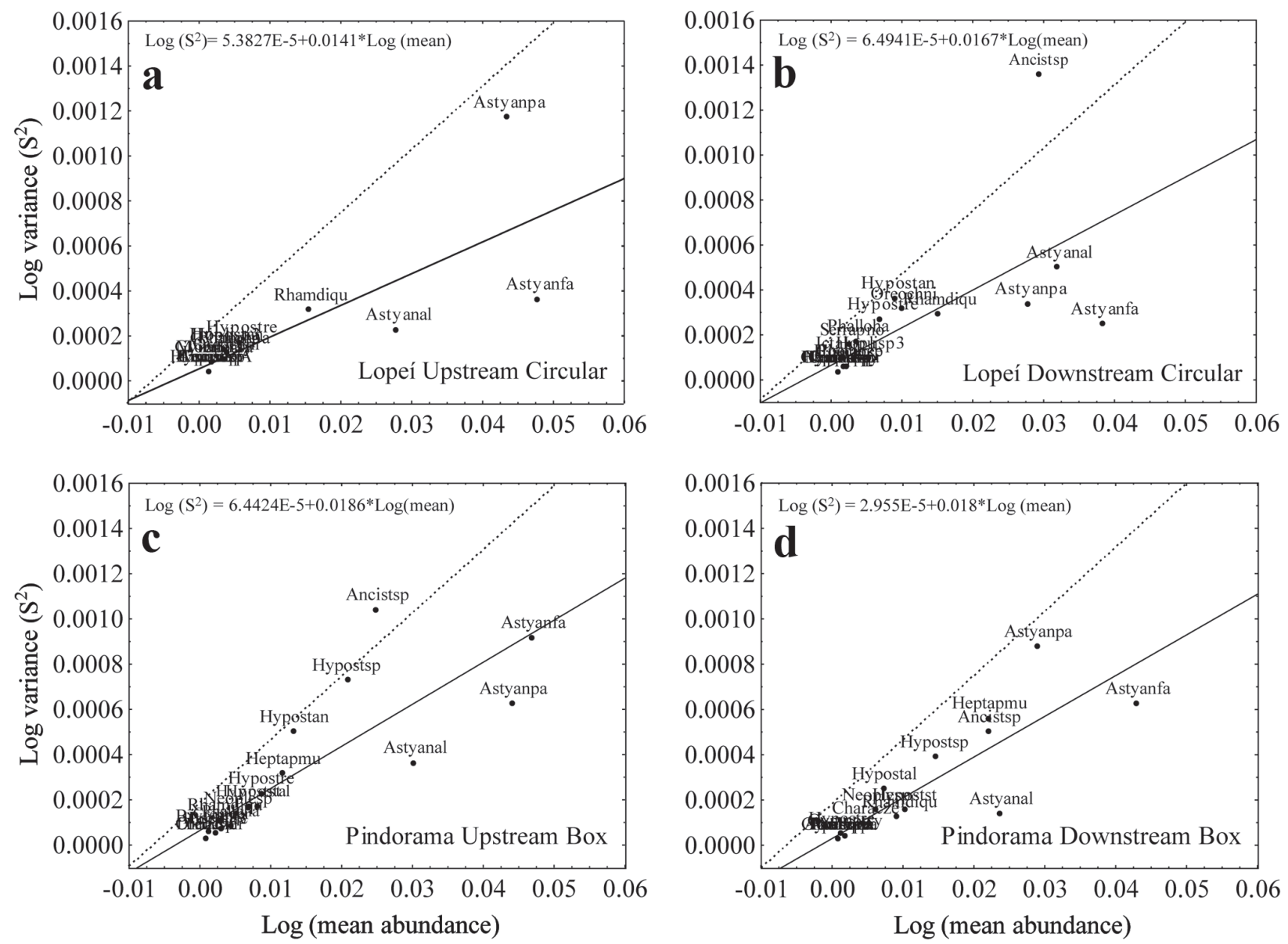

Fig. 12. Spatial aggregation of fish species in the sampled stretches of the Lopeí stream - circular culvert (a - b) and Pindorama stream - box culvert $(\mathbf{c}-\mathbf{d})$.

culvert. These values were similar between stretches of the box culvert. Nislow et al. (2011) observed that in culverts considered as impassable to fish in the USA, species richness and abundance were lower in the upstream stretch, whereas in passable culverts they were similar between stretches. However, Pluym (2006) observed that species richness in controlled water flows did not vary with the type of structure of water passage. Wellman et al. (2000), in Tennessee (USA), also observed that diversity, abundance, and richness were not different between upstream and downstream stretches, or between culverts and sites of free passage.

Variances in the composition of fish assemblages between upstream and downstream stretches of the culverts, in particular of the circular culvert, indicate that it can be affecting the distribution of the ichthyofauna and altering its composition (Newbrey et al., 2001). The culverts used extensively for water passage and fluvial drainage in the crossings of small streams (Kapiztke, 2010) create potential problems for the passage of fish, and culvert installations can significantly decrease the probability of fish movement between habitat patches (Schaefer et al., 2003).
Our study although limited to two culverts, one of each type (one box and one circular) indicated variations in the species abundance, richness, and diversity between upstream and downstream stretches of the circular culvert in the Lopeí stream, suggesting that fish movements are restrained more intensively in this culvert, particularly for Siluriformes. The drop in the circular culvert outlet probably created passage barriers especially for those fish that has no ability to jump, where downstream erosion could lead to culvert perching. Studies on appropriate crossing design or installation are fundamental whereas improvements in these structures can restore the connectivity of fish populations and communities in streams (Nislow et al., 2011). The longitudinal connectivity in streams is essential for the maintenance of healthy environments, pointing out to the need of further studies in Neotropical streams intercepted by culverts focused on fish assemblages and their movement. Such studies may help the sectors responsible for implementing road crossings in order to propose possible solutions to improve the habitat conditions. 


\section{Acknowledgments}

We thank National Council for Scientific and Technological Development (CNPq) for Productivity in Research-PQ (MCM) scholarship and financial support, CAPES (JRM) and "Parque Tecnológico de Itaipu" (PTI) (EFC) for the scholarship.

\section{Literature Cited}

Abes, S. S., \& A. A. Agostinho. 2001. Spatial patterns in fish distributions and structure of the ichthyocenosis in the Água Nanci stream, upper Paraná river basin, Brazil. Hydrobiologia, 445: 217-227.

Agostinho, A. A. \& T. Penczak. 1995. Populations and production of fish in two small tributaries of the Paraná river, Paraná, Brazil. Hydrobiology, 312: 153-166.

Becker, F. G. 2002. Distribuição e abundância de peixes e suas relações com características de habitat local, bacia de drenagem, e posição espacial em riachos de Mata Atlântica (bacia do rio Maquiná, RS, Brasil). Unpublished Ph.D. Thesis, Universidade Federal de São Carlos, São Carlos, 190p

Benton, P. D, W. E. Ensign \& B. J. Freeman. 2008. The effect of road crossings on fish movement in small Etowah basin streams. Southeastern Naturalist, 7: 301-310.

British Columbia Ministry of Transportation and Highways. 2000. Culverts and Fish Passage, Enviromental Management Section, Egineering Branch, 1664-2-4.

Bührnheim, C. M. 2002. Heterogeneidade de habitat: rasos e fundos em assembléias de peixes de igarapés de terra firme na Amazônia Central. Revista Brasileira de Zoologia, 19: 889-905.

Burford, D. D., T. E. Mcmahon, J. E. Cahoon \& M. Blank. 2009. Assessment of Trout Passage through Culverts in a Large Montana Drainage during Summer Low Flow. North American Journal of Fisheries Management, 29: 739-752.

Cahoon, J. E., T. McMahon, A. Solcz, M. Blank \& O. Stein. 2007. Fish Passage in Montana culvert: Phase II- Passage goals, FHWA,MT,07,010,8181, Final Report.

Callisto, M., W. Ferreira, P. Moreno, M. D. C. Goulart \& M. Petrucio. 2002. Aplicação de um protocolo de avaliação rápida da diversidade de habitat em atividades de ensino e pesquisa. Acta Limnologica Brasiliensia, 13: 91-98.

Castro, M. A., H. A. Santos, F. A. C. Sampaio \& P. S. Pompeu. 2010. Swimming perfomance of the small characin Bryconamericus stramineus (Characiformes: Characidae). Zoologia, 27: 939-944.

Castro, R. M. C., L. Casatti, H. F. Santos, A. L. A. Melo, L. S. F Martins, K. M. Ferreira, F. Z. Gibran, R. C. Benine, M. Carvalho, A. C. Ribeiro, T. X. Abreu, F. A. Bockmann, G. Z. P. Pelição, R. Stopiglia \& F. Langeani. 2004. Estrutura e composição da ictiofauna de riachos da bacia do Rio Grande, no Estado de São Paulo, Sudeste do Brasil. Biota Neotropica, 4: 1-39.

CDFG. 2002. Culvert criteria for fish passage. State of California Resources Agency Department of Fish and Game, 17p.

Celestino, E., E. A. L. Kashiwaqui, S. Makrakis, M. C. Makrakis \& J. R. Mariano. 2012. Métodos de coleta para avaliação longitudinal da ictiofauna em riachos interceptados por tubulações. Pp. 115-136. In: Baggio. A. (Ed.). Ecologia de Estradas: tendências e pesquisas. Lavras, Editora UFLA, 313p.

Corgosinho, P. H. C., L. S. F. Calixto, P. L. Fernandes, L. M. Gagliardi \& V. L. P. Balsamão. 2004. Diversidade de habitats e padrões de diversidade e abundância dos bentos ao longo de um afluente do reservatório de Três Marias, MG. Arquivos do Instituto Biológico, 71: 227-232.

Cunico, A. M., A. A. Agostinho \& J. D. Latini, 2006. Influência da urbanização sobre as assembléias de peixes em três córregos de Maringá, Paraná. Revista Brasileira de Zoologia, 23: 1101-1110. Dajoz, R. 1978. Ecologia Geral. Rio de Janeiro, Editora Vozes. 472p. Dala-Corte, R. B., I. Franz \& M. P. Barros. 2009. A survey of the ichthyofauna at Floresta Nacional de Canela, in the upper region of Rio Caí basin, Rio Grande do Sul, Brazil. Biota Neotropica, 9: 221-229.

Dane, B. G. 1978. Culvert guidelines: recommendations for the design and installation of culverts in British Columbia to avoid conflict with anadromous fish. Tech. Rep. 811.Department of Fisheries and Environment, Fisheries and Marine Service, Vancouver, BC, 57p.

DNIT - Departamento Nacional de Infraestrutura de Transportes. 2004a. Drenagem - bueiros metálicos executados sem interrupção do tráfego. NORMA DNIT 024/2004 - ES, 8p.

DNIT - Departamento Nacional de Infraestrutura de Transportes. 2004b. Drenagem - bueiros celulares de concreto. NORMA DNIT 025/2004 - ES, 8p.

DNIT - Departamento Nacional de Infraestrutura de Transportes. 2006. Drenagem - bueiros tubulares de concreto. NORMA DNIT 023/2006 - ES, 8p.

Fitzpatrick, F. A., I. R. Waite, P. J. D’Arconte, E. M. R. Meador, M. A. Maupin \& M. E. Gurtz. 1998. Revised Methods for Characterizing Stream Habitat in the National Water-Quality Assessment Program. U.S. Geological Survey Water-Resource Investigations Report 98-4052. US Geological Survey, Reston, Virginia.

Foltz, R. B., Y.A. Yanosek \& T. M. Brown. 2008. Sediment concentration and turbidity changes during culverts removals. Journal of Environmental Management, 87: 329-340.

Formam, R. T. T. \& L. E. Alexander. 1998. Roads and their major ecological effects. Annual Review of Ecology and Systematics, 29: 207-231.

Gardner, A. N. 2006. Fish Passage through Road Culverts. (Under the direction of Dr. Greg Jennings), Faculty of North Carolina State University, Biological and agricultural engineering.

Garutti, V. 1988. Distribuição longitudinal da ictiofauna em um córrego da região noroeste do Estado de São Paulo, bacia do rio Paraná, Rio de Janeiro. Revista Brasileira de Biologia, 48: 747-759.

Gauch, H.G. Jr. 1982. Multivariate Analysis in Community Ecology. Cambridge Studies in Ecology. Cambridge University Press, Cambridge, 298p.

Gibson, R. J., R. L. Haedrich \& C. M. Wernerheim. 2005. Loss of fish habitat as a consequence of inappropriately constructed stream crossings. Fisheries, 30: 10-17.

Graça, W. J. \& C. S. Pavanelli. 2007. Peixes da planície de inundação do alto rio Paraná e áreas adjacentes. Maringá, Eduem, 241p.

Hoffman, R. \& J. Dunham. 2007. Fish movement ecology in high gradient headwater streams: its relevance to fish passage restoration through stream culvert barriers. U.S. Geologic Survey, OFR 2007-1140, 1-37.

Hotckiss, R. S. \& C. M. Frei. 2007. Design for Fish Passage At Roadway Stream Crossings: Synthesis Report. U.S Department of Transportation, Federal Highway Administration, Office of Highway Infrastructure and Research. FHWA-HIM-07-033.

Kapitzke, R. 2010. Culvert Fishway Planning and Design Guidelines, School of Engineering and Physical Sciences, James Cook University, Townsville, Australia. 
Katopodis, C., P. R. Robinson \& B. G. Sutherland. 1978. A study of model and prototype culvert baffling for fish passage. Fisheries \& Marine Service Technical Report, 828: 78p.

Katopodis, C. 1993. Fish passage at culvert highway crossings Highways and the Environment, Charlottetown, 26p.

Kemp, P. S. \& J. G. Williams. 2008. Response of migrating Chinook salmon (Oncorhynchus tshawytscha) smolts to in-stream structure associated with culverts. River Research and Applications, 24: 571-579.

Langeani, F., L. Casatti \& H. S. Gameiro. 2005. Riffle and pool fish communities in a large stream of southeastern Brazil. Neotropical Ichthyology, 3: 305-311.

Langill, D. A. \& P. J. Zamora. 2002. An audit of small culvert installations in Nova Scotia: habitat loss and habitat fragmentation. Canadian Technical Report of Fisheries and Aquatic Sciences, 2422.

Ludwing, J. A. \& J. F. Reynolds. 1988. Statistical ecology: a primer on methods and computing, New York, John Wiley \& Sons.

Magurran, A. E. 1988. Ecological diversity and its measurement. London, Croom Helm, 179p.

Mathews, W. J. 1998. Patterns in freshwater fish ecology. New York, Chapman \& Hall. 756p.

Maurer, B. A. 1994. Geographical population analysis: tools for the analysis of biodiversity. Blackwell Scientific Publications, Boston.

McKinley, W. R. \& R. D. Webb. 1956. A proposed corrections of migratory fish problems at box culverts. Fish Research Papers, 1: 33-45.

Metsker, H. E. 1970. Fish versus culverts, some considerations for resource managers. USDA, Forest Service Technical Report. ETR-7700-5. Ogden, UT, 19pp.

Morrinson, R. R., R. H. Hotckiss, M. Stone, D. Thurman \& A. R. Horner-Devine. 2009. Turbulence characteristics of flow in spiral corrugated culvert fitted with baffles and implications for fish passage, Portland, US. Ecological Enginering OR 07204-1134, 35: 381-392.

Naiman, R. J., H. Decamp \& M. E. McClain. 2005. Riparia: Ecology, Conservation and Management of Streamside Communities. Elsevier/Academic Press, San Diego.

NakataniI, K., A. A. Agostinho, G. Baumgartner, A. Bialetzki, P. V. Sanches, M. C. Makrakis \& C. S. Pavanelli. 2001. Ovos e larvas de peixes de água doce: desenvolvimento e manual de identificação. Maringá, EDUEM, 378p.

Newbrey, M. G., M. A. Bozek \& C. E. Edwardds. 2001. Effects of stream barriers as impediments to warmwater fish movement with an emphasis on culverts and siltation: an annotated bibliography. Grand Rapids, MX, Final report to USDA Forest Service, $52 \mathrm{p}$.

Nislow, K. H., M. Hudy, B. Letcher \& E. P.Smith. 2011. Variation in local abundance and species richness of stream shes in relation to dispersal barriers: implications for management and conservation. Freshwater Biology, 56: 2135-2144.

ODFW. 2004. Fish passage criteria. Oregon Department of Fish and Wildlife, $6 \mathrm{p}$

Park D., S. Michael, E. Bayne \& G. Scrimgeour. 2008. Landscapelevel stream fragmentation caused by hanging culverts along roads in Alberta's boreal forest. Canadian Journal of Forest Research, 38: 566-575.
Pavanelli, C. S. \& E. P. Caramaschi. 2003. Temporal and spatial distribution of the ichthyofauna in two streams of the upper Rio Paraná Basin. Brazilian Archives of Biology and Technology, 46: 271-280.

Perez, Jr., O. R. \& J. C. Garavelo. 2007. Ictiofauna do Ribeirão do Pântano, afluente do Rio Mogi-Guaçu, Bacia do Alto Rio Paraná, São Paulo, Brasil. Iheringia Zoology, 97: 328-335.

Pluym, J. L. V. 2006. Impact of Bridges and Culverts on Stream Fish Movement and Community Structure. Unpublished Ph.D. Thesis, North Carolina State University, 104p.

Poplar-Jeffers, I. 2005. Culvert Inventory and Effects on Fish Assemblages in a Central Appalachian Watershed. Davis College of Agriculture, Forestry, and Consumer Sciences at West Virginia University, Morgantown, West Virginia, 153p.

Santos, H. A., P. S. Pompeu \& C. B. Martinez. 2006. Determinação de capacidade natatória de peixes visando a otimmização dos mecanismos de transposição de peixes em usinas hidrelétricas. Comitê Brasileiro de barragens, V Simpósio Brasileiro Sobre Pequenas e Médias Centrais Hidrelétricas, T18 -A06

Santos, H. A., P. S. Pompeu \& C. B. Martinez. 2007. Swimming performance of the migratory Neotropical fish Leporinus reinhardti (Characiformes: Anostomidae). Neotropical Ichthyology, 5:139-146.

Schaefer, J. F., E. Marsh-Matthews, D. E. Spooner, K. B. Gido \& W. J. Matthews. 2003. Effects of barriers and thermal refugia on local movements of threatened leopard darter, Percina pantherina. Environmental Biology of Fishes, 66: 391-400.

Taylor, L. R. 1961. Aggregation, variance and the mean. London, Nature, 189: 732-735

Tundisi, J. G. \& T. Tundisi. 2008. Limnologia, São Paulo: Oficina de Textos, 632p.

Uieda, V. S. \& R. M. C. Castro. 1999. Coleta e fixação de peixes de riachos. Pp. 1-22. In: Caramaschi, E. P., R. Mazzoni \& P. R. Peres-Neto (Eds.). Ecologia de peixes de riachos. Oecologia Brasiliensis, 260p.

Uieda, V. S. 1984. Ocorrência e distribuição dos peixes em um riacho de água doce. Brazilian Journal of Biology, 44: 75-84.

WDFW. 2003. Design of road culverts for fish passage. Washington Department of Fish and Wildlife publication, 111p.

Wellman, J. C., D. L. Combs \& S. B. Cook. 2000. Long term impacts of bridge and culvert construction on replacement of fish communities and sediment Characteristics of Streams. Journal of Freshwater Ecology, 15: 317-328.

Wheeler, A. P., P. L. Angermeier \& A. E. Rosenberger. 2005. Impacts of new highways and subsequent landscape urbanization on stream habitat and biota. Reviews in Fisheries Science, 13: 141-164.

Winemiller, K. O. 1996. Dynamic diversity in fish assemblages of tropical rivers. In: Cody M. L., \& J. A. Smallwood (Eds.), Long Term Studies of Vertebrate Communities. Academic Pess Inc, San Diego, 99-134.

Zrinji, Z. \& M. Bender. 1995. Experimental Risk Evaluation for Baffled Culvert Fishway Design. Winnipeg, MB. University of Manitoba, Department of Civil and Geological.Engineering, Water Resources Research.

Submitted March15, 2012 Accepted September 3, 2012 